\title{
ANALISIS BAGAN AKTANSIAL CERITA ANAK JEPANG URASHIMA TARO
}

\author{
Rita Susanti \\ Jurusan Bahasa dan Sastra Jepang, Fakultas Sastra, Universitas Nasional, \\ Jl. Sawo Manila, Pejaten, Pasar Minggu, Jakarta \\ uniritas@yahoo.co.jp
}

\begin{abstract}
Thisi research is a kind of a research focusing on linguistic which uses semiotic in order to find out what lies behind the content of a children's story. The subject of this research is an ancient story of a Japanese children called mukashi banashi. It comes with the title of Urashima Taro which has been translated into Indonesia Language. Through semiotic analysis, the story may be conducted in a syntaxical and semantical way. According to syntax analysis, there are two episodes in the story. In this first episode Urashima Taro becomes the subject of the research while in the latte, the turtle is the subject. We may learn that the story plott and the flow of the story have gone through a flashback process. In the structure or "batih", it is known that the story has a complex relationship due to its expansion plot. Based on the semantic analysis, it is also know that the main/lead character of the story is Urashima Taro and the other characters are Urashima Taro's mother and the queen. The morale message of the whole story is dedicated to all children reading it.
\end{abstract}

Keywords: children story, semiotic

\begin{abstract}
ABSTRAK
Penelitian ini adalah penelitian pada bidang sastra yang menggunakan semiotika untuk menngetahui makna apa yang terkandung dalam cerita anak. Cerita anak yang dijadikan fokus penelitian adalah cerita anak Jepang zaman dahulu mukashi banashi, berjudul Urashima Taro yang telah diterjemahkan ke dalam bahasa Indonesia. Melalui semiotika analisis cerita dapat dilakukan secara sintaksis dan semantik. Berdasarkan analisis sintaksis, ada dua episode dalam cerita anak tersebut. Episode pertama yang menjadi subjek adalah Urashima Taro dan pada episode kedua, yang menjadi subjek adalah kura-kura.Selain itu, dapat diketahui alur penceritaan dan pengaluran yang mengalami satu tahapan cerita kembali ke belakang. Pada struktur batih diketahui awal cerita mempunyai hubungan yang bercabang. Berdasarkan analisis semantik, dapat diketahui bahwa tokoh utama dalam cerita anak tersebut adalah Urashima Taro dan tokoh bawahannya adalah ibu Urashima Taro dan ratu. Pesan moral kepada anak-anak merupakan makna yang terkandung dalam cerita tersebut.
\end{abstract}

Kata kunci: cerita anak, Urashima taro, bagan aktansial 


\section{PENDAHULUAN}

Semiotika akhir-akhir ini banyak digunakan untuk menganalisis sebuah karya sastra. Dulu kita ketahui cara menganalisis karya sastra, terutama pada novel, cerita pendek, dan lainnya hanya terfokus pada tokoh, penokohan, dan alur.

Semiotika berasal dari bahasa Yunani semion, berarti tanda. Jadi, semiotika adalah studi tentang tanda. Menurut Sudjiman dan Zoest (1992:5) semiotika adalah studi tentang tanda dan segala yang berhubungan dengannya, cara berfungsinya, dan mempergunakannya. Semiotika terdiri atas tiga bagian, yaitu sintaks semiotika (studi tanda yang berpusat pada penggolongannya dan menonjolkan hubungan tanda dengan tanda lainnya), semantik semiotika (studi tanda yang menonjolkan hubungan tanda-tanda dengan acuannya dan dengan interpretasi yang dihasilkannya), serta pragmatic semiotika (studi tanda tentang hubungan antara tanda dengan pengirim dan penerimanya).

Karya sastra yang akan diteliti adalah cerita anak-anak Jepang. Analisis cerita dilakukan secara semiotika dan menggunakan teori Todorov Tzvetan dan A.J Greimas (Budiman, 2004). Menurut Todorov analisis cerita dapat dilakukan dengan tiga aspek naratif, yaitu aspek sintaksis (kombinasi berbagai unit struktur atau in presentia), aspek semantik (isi cerita), dan aspek verbal atau pragmatik (manipulasi istilah maupun frasa). Namun, yang akan digunakan dalam penelitian in hanya aspek sintaksis dan aspek semantik. Sementara itu, teori Greimas tentang aktan dan fungsi digunakan untuk menganalisis alur cerita yang merupakan bagian dari analisis sintaksis.

Cerita anak Jepang dengan judul Urashima Taro menceritakan tentang kehidupan Urashima dengan ibunya. Mereka hidup dalam kemiskinan. Pada suatu hari Urashima menolong seekor kurakura dan sebagai balas budi kura-kura mengajak Urashima ke istana bawah laut. Tanpa pamit kepada ibunya, Urashima pergi bersama kura-kura. Kehidupan di istana bawah laut membuat Urashima lupa kepada ibunya. Pada suatu waktu, tiba-tiba Urashima teringat kembali akan ibunya dan akhirnya, ia berpamitan kepada ratu sebagi pemilik istana. Urashima pulang dengan membawa hadiah kotak yang tidak boleh dibuka dalam keadaan apa pun, lalu Urashima diantar oleh kura-kura ke pantai. Betapa terkejutnya Urashima ketika ia tidak menemukan rumah dan ibunya. Orang-orang kampung mengatakan bahwa ibunya telah lama meninggal. Urashima bingung, ia tidak tahu lagi apa yang harus dilakukan. Kemudian Urashima membuka kotak pemberian ratu dan terjadi perubahan drastis pada diri Urashima, ia berubah menjadi seorang kakek tua dan tak lama kemudian menjadi burung bangau.

\section{Kerangka Teori}

\section{Analisis Sintaksis}

Teori sintaksis atau hubungan in prasentia digunakan untuk menganalisis alur cerita. Istilah ini digunakan untuk menunjukkan serangkaian peristiwa yang saling berkaitan secara logis dan disebabkan oleh suatu tindakan. Analisis secara sintaksis terdiri atas.

\section{Aktan dan Fungsi}

Analisis aktan dan fungsi merupakan analisis alur cerita yang didasari hubungan antar aktan. Menurut Greimas tidak satu pun cerita dapat menjadi suatu totalitas yang bermakna tanpa didasari struktur aktansial. Setiap unsur yang ada di bagan disebut dengan bagan aktansial dan aktan-aktannya diteliti melalui tindakan. Aktan adalah sesuatu yang menyempurnakan atau menjalani perbuatan. Aktan dapat berupa orang, pelaku yang dipersonifikasikan, mengacu pada binatang, suatu barang, atau keberadaan yang abstrak. Berikut ini adalah bagan aktansial Greimas. 


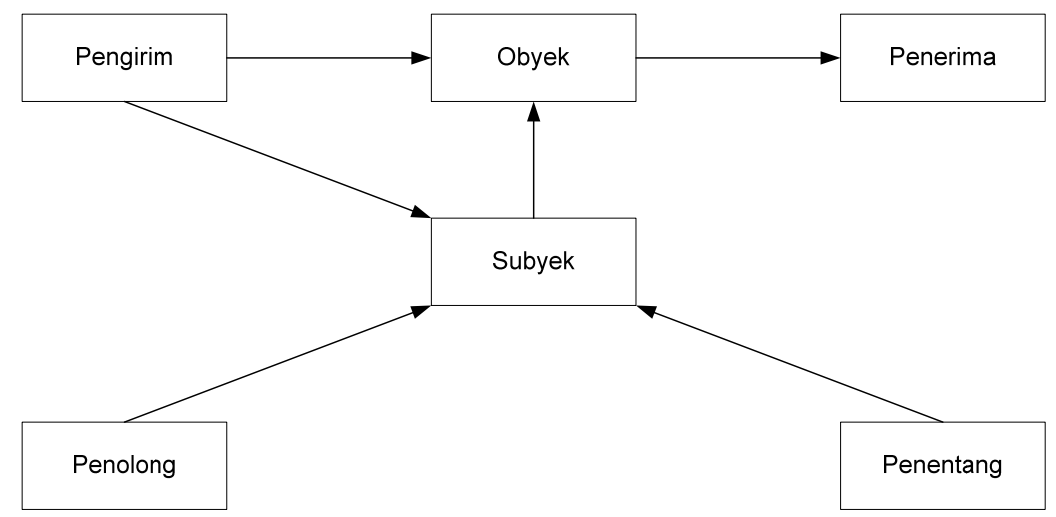

Gambar 1 Bagian aktansial Greimas (Greimas, 1972)

Pada bagan aktansial di atas terdapat enam aktan, sebagai berikut.

- Pengirim adalah pihak yang mempunyai karsa untuk meraih objek.

- Objek adalah sesuatu yang ingin diraih oleh keinginan si pengirim.

- Subjek adalah seseorang yang mengemban tugas dari si pengirim. Subjeklah yang melakukan pencarian objek.

- Penolong adalah pihak yang membantu subjek dalam pencarian objek.

- Penentang adalah pihak yang menghalangi subjek dalam pencarian objek.

- Penerima adalah pihak yang akan menikmati dan menerima objek yang berhasil diraih oleh subjek.

\section{Bagan Fungsional dan Fungsi}

Fungsional atau bagan fungsional terdiri atas (1) situasi awal; pengirim mengirimkan keinginan atau kewajiban akan perbuatan kepada penerima. (2) transformasi; terdiri atas cobaan awal, subjek memperoleh kecakapan yang diperlukan untuk melakukan perbuatan atau misi yang direncanakan, cobaan utama, mengacu kepada peristiwa atau perbuatan yang utama, subjek sudah dipersiapkan dan objek penyelidikan dipertaruhkan, cobaan akhir, pada tahapan ini hasil peristiwa sudah tampak, yaitu berhasil atau tidak. (3) situasi akhir; menggambarkan keadaan pada tahap akhir dari subjek.

\section{Analisis Semantik}

Analisis semantik disebut sebagai analisis in absentia. Aspek semantik adalah hubungan antara unsur yang hadir dan unsur yang tidak hadir dalam teks. Analisis semantik terdiri atas, tokoh, ruang, dan waktu (latar). Analisis tokoh difokuskan pada analisis perawakan, sifat, dan pikiran. Tokoh dapat apa saja, seperti, individu, binatang dan sebagainya.

\section{PEMBAHASAN}

\section{Analisis Sintaksis}

\section{Analisis dengan Bagan Aktansial}

Pada bagan aktansial menggambarkan episode-episode yang terjadi dalam cerita anak tersebut. 
Episode I

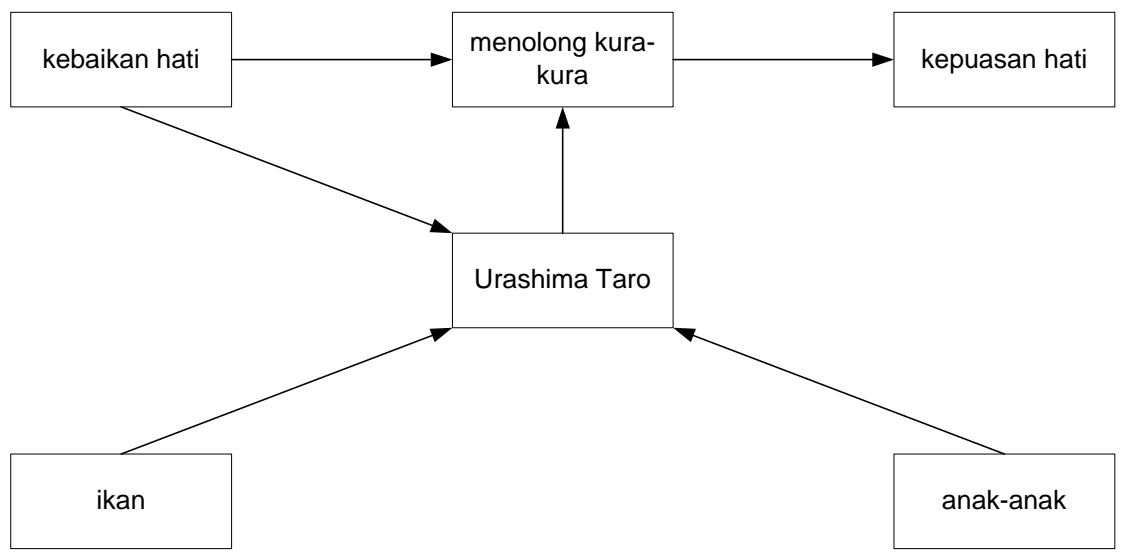

Gambar 2 Episode I Cerita Urashima Taro

Episode II

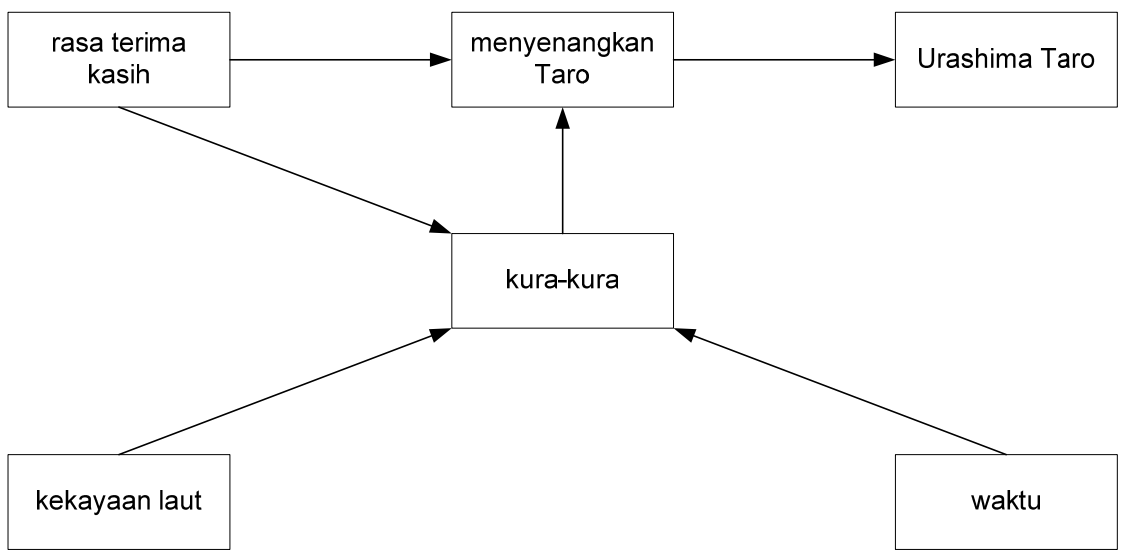

Gambar 3 Episode II Cerita Urashima Taro

Cerita yang dianalisis dengan bagan aktansial ini, terdiri atas dua episode. Pada episode pertama, subjek adalah Urashima Taro, karena dialah yang mengemban tugas dari pengirim, yaitu kebaikan hati. Objeknya adalah menolong kura-kura dan penerimanya adalah kepuasan hati dari Urashima Taro. Penolong adalah ikan, karena dengan ikan tangkapannya Urashima dapat menolong kura-kura, sedangkan penentang adalah anak-anak yang menyakiti kura-kura.

Episode dua, subjek berubah menjadi kura-kura, karena kura-kura ingin mengungkapkan rasa terima kasih. Rasa terima kasih ini sebagai pengirim. Objeknya adalah menyenangkan Urashima Taro dan penerima adalah Urashima Taro. Penolong adalah kekayaan laut yang dapat membuat senang hati Urashima dan penentangnya adalah waktu yang terbatas bagi Urashima untuk berada di bawah laut.

\section{Analisis dengan Bagan Fungsional}

Bagan fungsional menggambarkan tahapan dari situasi awal, transformasi, dan situasi akhir. 
Tabel 1 Bagan fungsional cerita Urashima Taro

\begin{tabular}{|c|c|c|c|c|}
\hline \multirow[t]{2}{*}{ Situasi Awal } & \multicolumn{3}{|c|}{ Transformasi } & \multirow[t]{2}{*}{ Situasi Akhir } \\
\hline & Cobaan Awal & Cobaan Utama & Cobaan Akhir & \\
\hline $\begin{array}{l}\text { Urashima dan } \\
\text { ibunya hidup } \\
\text { miskin }\end{array}$ & $\begin{array}{l}\text { Menolong } \\
\text { kura-kura }\end{array}$ & $\begin{array}{l}\text { Menikmati } \\
\text { kemewahan }\end{array}$ & $\begin{array}{l}\text { Kembali pada } \\
\text { keadaan semula }\end{array}$ & $\begin{array}{l}\text { Urashima } \\
\text { sebagai } \\
\text { bangau }\end{array}$ \\
\hline & Berhasil & Berhasil & Gagal, jadi tua & \\
\hline
\end{tabular}

Bagan fungsional hanya dibuat satu, walaupun bagan aktansialnya ada dua. Hal tersebut dikarenakan ketidakjelasan fungsi kura-kura pada cerita anak tersebut.

Pada bagan ini situasi awal digambarkan Urashima Taro dan ibunya hidup dalam kemiskinan. Pada tahapan transformasi yang terdiri atas tiga cobaan Urashima mengalami kegagalan dan juga keberhasilan. Cobaan awal, Urashima menolong seekor kura-kura yang diganggu oleh anak-anak dan ia berhasil menolongnya. Cobaan utama, Urashima menikmati kemewahan sebagai ungkapan rasa terima kasih kurakura dan ini pun berhasil. Cobaan akhir, Urashima mengalami kegagalan dan kembali pada keadaan semula. Situasi akhir digambarkan dengan berubahnya urashima menjadi burung bangau.

\section{Alur Penceritaan}

Alur penceritaan menggambarkan alur cerita yang sebenarnya, berisi poin-poin penting yang disebut juga dengan sekuen. Berikut ini sekuen dari cerita anak tersebut.

1. Kehidupan Urashima dan ibunya dalam kemiskinan

2. Urashima pergi memancing untuk makan

3. Menolong kura-kura yang disiksa teman-temannya

4. Menukar ikan tangkapan dengan kura-kura

5. Urashima dan ibunya tidak dapat makan

6. Bertemu kembali dengan kura-kura

7. Diajak kura-kura ke istana bawah laut

8. Memakan bola ajaib agar dapat bernafas di dalam laut

9. Ratu dan pengawal menyambut Urashima

10. Urashima dijamu dengan kemewahan istana bawah laut

11. Meninjau istana bawah laut dengan empat pintu ajaib, ditemani oleh ratu

12. Memasuki pintu pertama, kamasr musim semi dengan keindahan bunganya

13. Memasuki pintu kedua, kamar musim panas dan berenang di sungai

14. Memasuki pintu ketiga, kamar musim gugur dengan hidangan kuenya

15. Memasuki pintu keempat, kamar musim dingin dengan hamparan saljunya

16. Teringat akan ibunya dan memohon diri untuk kembali ke rumah

17. Ratu menyerahkan kotak sebagai hadiah dengan syarat tidak boleh dibuka

18. Kembali ke pantai dengan menunggang kkura-kura

19. Bertanya kepada penduduk desa tentang ibu dan rumahnya

20. Cerita penduduk desa: ibu dan rumahnya sudah tidak ada

21. Urashima menangis, ternyata ibunya sudah meninggal

22. Urashima membuka kotak dan menjadi kakek-kakek tua

23. Berubah menjadi burung bangau 
Alur penceritaan ini terdiri atas dua puluh tiga sekuen yang menggambarkan perjalanan tokoh utama, yaitu Urashima Taro dari kehidupan awalnya dengan ibunya yang berada dalam kemiskinan. Akan tetapi, Urashima pun sempat menikmati kemewahan, yaitu kemewahan istana bawah laut, hal ini sebagai ungkapan rasa terima kasih kura-kura karena pernah ditolong oleh Urashima. Namun, kemewahan itu hanya sesaat dan ketika Urashima kembali ke pantai untuk menemui ibunya, kemewahan itu hilang serta ia pun tidak dapat bertemu dengan ibunya, karena menurut penduduk desa ibunya sudah meninggal. Ternyata kehidupan di bawah laut yang dirasakan hanya sebentar kira-kira dua sampai tiga bulan oleh Urashima di dunia nyata (di daratan) sudah seratus tahun. Hadiah yang diberikan oleh ratu dibuka oleh Urashima, lalu ia pun berubah menjadi seorang kakek tua dan kemudian burung bangau.

\section{Pengaluran}

Pengaluran adalah hal yang menjelaskan bagaimana alur ditampilkan atau dengan kata lain, pengaluran berisi fakta-fakta yang ada di lapangan. Adapun pengaluran pada cerita anak Urashima Taro sebagai berikut.

$$
1-2-3-4-5-6-7-8-19-10-11-12-13-14-15-16-17-18-20-21-22-23
$$

Hasil dari pengaluran, cerita tersebut berlangsung dengan tahapan teratur. Ada terdapat satu tahapan cerita kembali ke belakang, yaitu peristiwa ibu Urashima sudah meninggal seratus tahun yang lalu. Hal tersebut disadari oleh Urashima ketika ia kembali ke pantai dan bertanya kepada penduduk desa.

\section{Struktur Batih}

Struktur batih atau disebut juga hubungan sebab akibat pada analisis ini menggambarkan hubungan yang terjadi dan akibat yang didapat dari luar cerita anak Urashima Taro. (Gambar 4)

Berdasarkan struktur batih yang sudah digambarkan di atas, dapat dilihat pada awal cerita ada hubungan bercabang. Struktur nomor II dan III bergabung sehingga terjadi penukaran dengan ikan tangkapan. Struktur nomor V dan VII bergabung menjadi si ibu tinggal sendiri dan selalu bersedih hati. Pada akhir cerita, alur penceritaan berjalan teratur.

\section{Analisis Semantik}

Analisis semantik yang akan dibahas, yaitu tokoh pada cerita anak Urashima Taro adalah tokoh utama dan tokoh bawahan.

Tokoh utama adalah Urashima Taro. Urashima menjadi tokoh utama karena ia memegang peranan penting atau tokoh sentral, bahkan menjadi pusat sorotan cerita. Urashima adalah seorang anak yang berbakti kepada orang tua. Setiap hari ia pergi memancing ikan untuk mencukupi makan bagi dirinya sendiri dan ibunya. Ia tidak ingat akan ibunya, ketika berada di bawah laut. Hal itu disebabkan oleh kekuatan ratu istana bawah laut. Walaupun kekuatan ratu sangat kuat, tetapi ingatan Urashima akan ibunya kembali lagi, saat ratu menghidangkan kue mochi. Lalu Urashima berpamitan untuk kembali ke pantai menemui ibunya.

Tokoh bawahan adalah ibu Urashima dan ratu. Disebut tokoh bawahan karena tokoh yang tidak sentral kedudukannya di dalam cerita, tetapi kehadirannya sangat diperlukan untuk mendukung tokoh utama. Ibu Urashima adalah seorang ibu yang sangat sayang kepada anaknya. Ketika Urashima tidak kembali dari memancing ikan, ia menangis setiap hari sampai akhirnya meninggal dunia. Tokoh ratu sebenarnya adalah tokoh yang tahu membalas budi, yaitu dengan menjamu Urashima secara berlebihan. Akan tetapi, karena kekuatannya ada terkesan ratu berperilaku jahat, karena membuat pikiran Urashima lupa akan ibunya dan juga membuat Urashima selalu tampak muda. 


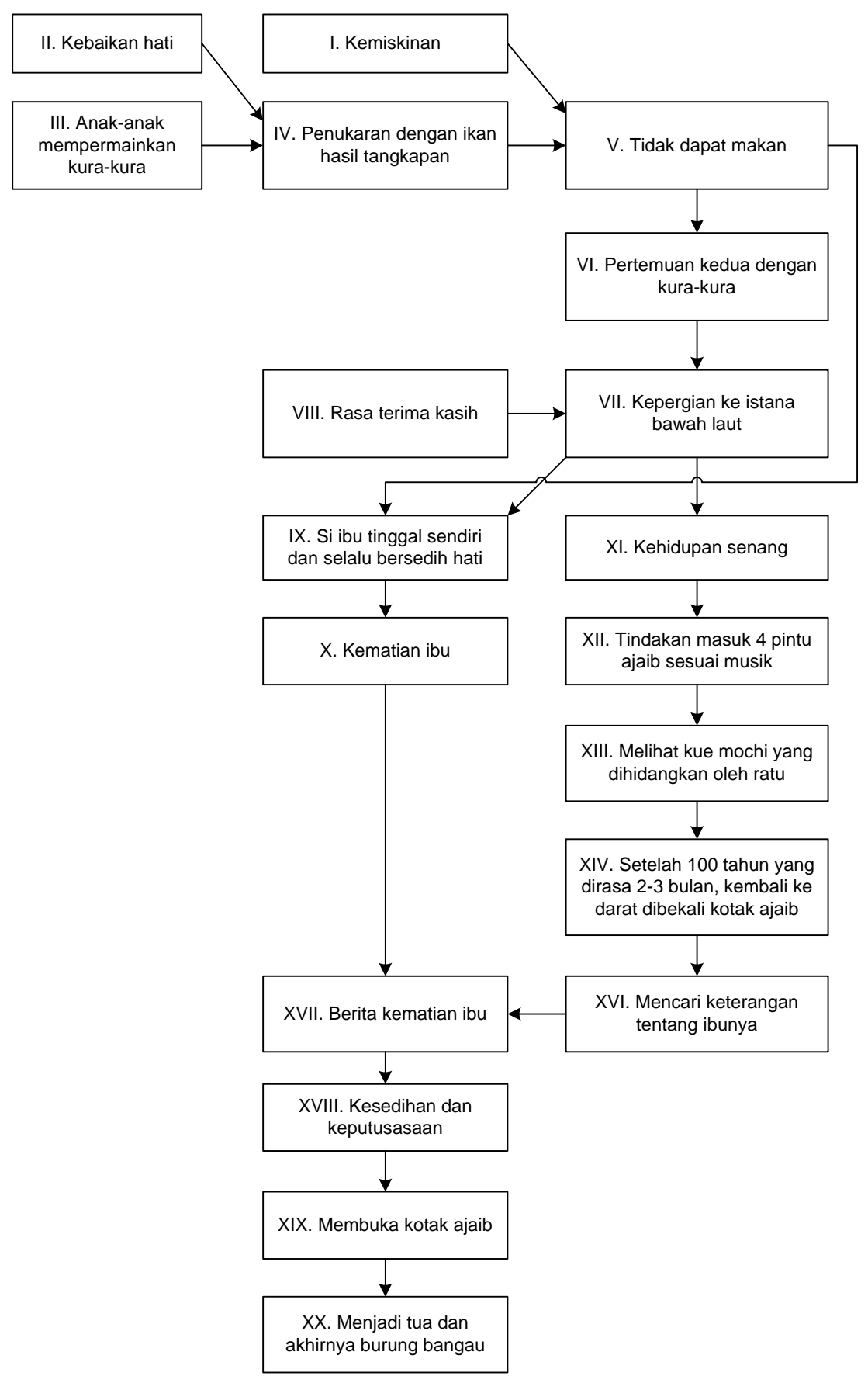

Gambar 4 Struktur cerita Urashima Taro

\section{SIMPULAN}

Bagan aktansial yang dikemukakan oleh A.J. Greimas digunakan untuk menganalisis karya sastra berupa cerita anak. Penggunaan bagan aktansial menghasilkan dua episode di dalam cerita anak tersebut. Masing-masing episode menunjukkan subjek adalah Urashima dan kura-kura, objek adalah menolong kura-kura dan menyenangkan Urashima, pengirim adalah kebaikan hati dan rasa terima kasih, penerima adalah kepuasan hati dan Urashima, penolong adalah ikan dan kekayaan laut serta penentang adalah anak-anak dan waktu. Bagan fungsional pun dikerjakan berdasarkan atas teori 
Greimas. Situasi awal, Urashima dan ibunya hidup di dalam kemiskinan. Pada tahapan transformasi, cobaan awal dan cobaan utama mengalami keberhasilan, sedangkan cobaan akhir mengalami kegagalan, dan Urashima menjadi tua. Situasi akhir digambarkan dengan berubahnya Urashima menjadi burung bangau. Alur penceritaan atau disebut juga dengan sekuen, menggambarkan urutan cerita sejak Urashima tinggal di desa ditepi pantai sampai ia kembali lagi ke sana. Pada pengaluran tersebut terlihat kisah kembali mundur, yaitu Urashima baru menyadari kalau ibunya telah lama meninggal dunia. Ia menyadari hal itu ketika kembali ke pantai, lalu bertanya kepada penduduk desa dan hal ini dapat dilihat dengan jelas pada hubungan sebab akibat dalam struktur batih. Berdasarkan analisis di atas dapat ditarik suatu kesimpulan bahwa makna yang terkandung dalam cerita anak Urashima Taro adalah pesan moral pada anak-anak. Seorang anak tidak boleh melupakan orang tua baik dalam keadaan senang, maupun susah dan bila hendak pergi ke suatu tempat harus minta izin terlebih dahulu kepada orang tua.

\section{DAFTAR PUSTAKA}

Budiman, K. (2004). Imaji Tuhan Dalam Novel Chimmoku Karya Endo Shusaku Jakarta: Universitas Indonesia.

Greimas, A. J. (1972). Semantique Structurale. Paris: Larousse.

Hirata, Shogo. (1994). Urashima Taro, terj. Arina Abubakar. Jakarta: Elex Media Komputindo.

Sudjiman, P, \& Aart Van Zoest, A. V. (1991). Eds., Serba-Serbi Semiotika. Jakarta: Gramedia Pustaka Utama.

Zoest, Aart Van. (1991). Semiotika, terj. Ani Soekowati. Jakarta: Yayasan Sumber Agung.

\section{Lampiran}

\section{Sinopsis}

Pada zaman dahulu kala di Umabe jepang, hiduplah seorang nelayan bernama Urashima Taro yang tinggal bersama ibunya. Pada suatu hari, pagi-pagi sekali Urashima pergi memancing. Setelah lama menunggu dengan terpaan angina yang kuat, ia mendapatkan ikan untuk makan malamnya. Di tepi pantai, ketika ia bermaksud pulang ke rumah, dilihatnya anak-anak sedang membalik-balikan tubuh seekor kura-kura. Ia memphpn pada anak-anak untuk melepaskan kura-kura, tetapi anak-anak tersebut menolaknya. Akan tetapi, ketika Urashima menawarkan ikan tangkapan sebagai pengganti kura-kura, anank itu baru mau melepaskan kura-kura.

Beberapa waktu kemudian, ketika Urashima sedang memancing di laut, tibha-tiba muncul kura-kura yang pernah ditolongnya. Sekali lagi kura-kura itu mengucapkan terima kasih dan mengajak Urashima untuk berkunjung ke istana bawah laut. Urashima langsung menyetujuinya. Dengan memakan sebuah bola ajaib untuk dapat bernafas di dalam laut, lalu pergilah Urashima dengan menunggang kura-kura masuk ke dalam laut. Di sana sudah menanti ratu dan para dayang istana. Urashima disambut meriah dan dijamu dengan kemewahan istana bawah laut. Urashima diajak berkeliling istana serta menikmati kamar empat musim. Pada saat berada di kamar musim dingin, ratu menghidangkan kue mochi, tiba-tiba Urashima teringat akan ibunya, lalu ia mohon pamit pada ratu untuk ekmbali ke pantai. Dengan dibekali hadiah sebuah kotak, kembalilah Urashima ke pantai ditemani oleh kura-kura. 
Setelah tiba dipantai, segera Urashima berjalan menuju rumahnya. Ternyata rumahnya telah hancur dan Urashima terus berteriak ke sana kemari memanggil ibunya. Oleh karena, ia tidak menemukan ibunya, bertanyalah ia kepada penduduk desa. Mereka menjawab bahwa ibunya telah meningga seratus tahun yang lalu. Ibu Urashima meninggal karena manangis setiap hari memikirkan dirinya yang tidak pulang juga ke rumah. Urashima merasa putus asa dan akhirnya ia membuka kotak yang diberikan oleh ratu, kotak tersebut sebenarnya tidak boleh dibuka. Lalu dari dalam kotak keluarlah asap dan tak lama kemudian Urashima berubah menjadi kakek tua. Ternyata hidup yang diraskan sebentar di bawah laut sama dengan seratus tahun hidup didaratan. Dengan pelanggran itupun Urashima di akhir cerita berubah menjadi burung bangau. 